Article

\title{
Anaplasma and Theileria Pathogens in Cattle of Lambwe Valley, Kenya: A Case for Pro-Active Surveillance in the Wildlife-Livestock Interface
}

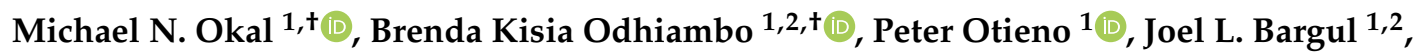 \\ Daniel Masiga ${ }^{1} \mathbb{D}$, Jandouwe Villinger $1, * \mathbb{C}$ and Shewit Kalayou $1, * \mathbb{1}$ \\ 1 International Centre of Insect Physiology and Ecology (icipe), P.O. Box 30772-00100 Nairobi, Kenya; \\ mnyanganga@icipe.org (M.N.O.); bodhiambo@icipe.org (B.K.O.); podhiambo@icipe.org (P.O.); \\ jbargul@icipe.org (J.L.B.); dmasiga@icipe.org (D.M.) \\ 2 Department of Biochemistry, Jomo Kenyatta University of Agriculture and Technology, \\ P.O. Box 62000-00200 Nairobi, Kenya \\ * Correspondence: jandouwe@icipe.org (J.V.); skalayou@icipe.org (S.K.) \\ + These authors contributed equally.
}

Received: 4 October 2020; Accepted: 4 November 2020; Published: 20 November 2020

\begin{abstract}
Tick-borne pathogens (TBPs) are major constraints to livestock production and a threat to public health in Africa. This cross-sectional study investigated the risk of infection with TBPs in cattle of Lambwe Valley, Kenya. Blood samples of 680 zebu cattle from 95 herds in six geospatial clusters within $5 \mathrm{~km}$ of Ruma National Park were screened for bacterial and protozoan TBPs by high-resolution melting analysis and sequencing of PCR products. We detected Anaplasma bovis $(17.4 \%)$, Anaplasma platys (16.9\%), Anaplasma marginale (0.6\%), Theileria velifera $(40 \%)$, and Theileria mutans (25.7\%), as well as an Anaplasma sp. (11.6\%) that matched recently reported Anaplasma sp. sequences from Ethiopia. Babesia, Rickettsia, and Ehrlichia spp. were not detected. The animal and herd-level prevalences for TBPs were 78.5\% (95\% confidence intervals (CI): 75.3, 81.5) and 95.8\% (95\% CI: 91.8, 99.8), respectively. About $31.6 \%$ of cattle were co-infected with 13 combinations of TBPs. The prevalence of TBPs differed between clusters and age, but the risk of infection was not associated with sex, herd size, or the distance of homesteads from Ruma. This study adds insight into the epidemiology of TBPs around Ruma and highlights the need for proactive surveillance of TBPs in livestock-wildlife interfaces.
\end{abstract}

Keywords: tick-borne pathogens; Anaplasma; Theileria; zebu cattle; wildlife-livestock interface; Kenya

\section{Introduction}

Wildlife-livestock interfaces, or areas where game and domesticated animals co-habit [1], support a plethora of interactions that can be of epidemiological concern [2]. Such interfaces are a haven for ticks and many other arthropod vectors of diseases maintained by wildlife [1]. Global trends suggest that emerging infectious diseases are on the rise, with up to $80 \%$ of animal pathogens and $71.8 \%$ of emerging zoonoses in some regions predicted to have a wildlife component [3,4]. Over the past two decades, there has been a heightened incidence of ticks and tick-borne pathogens (TBPs) across a wide geographical spread [3] and new tick-borne disease agents often discovered [5]. Many of these infectious diseases transmitted by ticks between domestic and wild animals represent emerging and re-emerging burdens to global public health, economies, and the conservation of biodiversity $[2,6]$. Astonishingly, there is limited information on the diversity and prevalence of TBPs in many areas, including the wildlife-livestock interfaces. Where available, data are dated and might not be beneficial for the strategic management and control of TBPs [6]. 
In sub-Saharan Africa, theileriosis, ehrlichiosis, babesiosis, and anaplasmosis spread by ticks are the leading causes of losses in livestock production [7]. Several TBPs have been identified in wildlife [8,9], ticks [9-11], and livestock, including small ruminants kept by nomads [12]. Coexistence with wildlife can increase the risk of TBPs in livestock and man [13]. The most important tick-borne disease in sub-Saharan Africa, the corridor disease caused by Theileria parva, is believed to have co-evolved with the African cape buffalo, a host immune to the pathogen, before "jumping hosts" to cattle [14]. More recently, studies have reported diverse TBPs in Kenya, including a novel Rickettsia sp. identified in ticks in the coastal Shimba Hills National Reserve [5]. A prevalence of up to 5.5\% spotted fever group rickettsioses was found in wildlife in Laikipia and the Maasai Mara National Reserve $[8,9]$. Tortoises in Baringo County and monitor lizards in Homa Bay County have been implicated as reservoirs of Ehrlichia ruminantium and Ehrlichia canis, respectively [10]. Similarly, Bunyamwera and West Nile viruses were identified from ticks collected from livestock and wildlife in Ijara District, northern Kenya [15]. These findings demonstrate the importance of wildlife in the circulation of diseases.

In Kenya, national parks, reserves, and conservancies account for about $11 \%$ of the country's landmass [16]. This is the direct result of wildlife conservation initiatives during the 1970s that led to the conversion of large portions of arid and semi-arid ecosystems, then considered to have little agricultural potential, into protected areas [1]. Ruma National Park, which occupies a third of Lambwe Valley in western Kenya, is a wildlife protected area where significant changes in land use have occurred over the last two decades [17]. In the last half century, intensive multiagency tsetse fly control activities in Lambwe Valley resulted in a marked decline in the incidence of trypanosomiasis [18] and contributed to the local elimination of human African sleeping sickness. The effective interventions impacted land use so that cultivated land increased by $22 \%$ over the last three decades [17]. Human populations on the periphery of the protected area have increased significantly [18], leading to an equivalent increase in livestock [19]. Such trends often increase the interactions between livestock, humans, and wildlife and may create a complex disease environment that leads to spill-over of diseases from wildlife to livestock and humans, and vice versa [20]. Despite the Ruma wildlife-livestock interface being a unique epidemiological niche of concern, empirical data on the epidemiology of TBPs circulating in livestock in the valley is limited.

Recently, smallholder farmers who reside within Lambwe Valley complained of episodes of outbreaks in livestock, causing significant fatality. Such reports also identified the presence of ticks and clinical signs compatible with haemoparasite infection in cattle. We hypothesised that the cattle were infected with TBPs and that cattle populations at the wildlife-livestock interface were at increased risk of TBP infection. We conducted a molecular epidemiological study to investigate the prevalence of TBPs and identify putative risk factors associated with exposure in cattle reared under a traditional system in the Lambwe Valley ecosystem.

\section{Materials and Methods}

\subsection{Study Area}

The study was carried out in Lambwe Valley, in village clusters around the Ruma National Park (Figure 1). Lambwe Valley (latitude $0^{\circ} 38^{\prime} 35.52^{\prime \prime} \mathrm{S}$, longitude $34^{\circ} 16^{\prime} 48^{\prime \prime} \mathrm{E}$ ) is $1200-1600 \mathrm{~m}$ above sea level and is infested by tsetse flies, the major vector for African trypanosomiasis. The terrain consists of rolling grasslands with open woodland and thickets dominated by acacia and a variety of grass species. The soil is predominantly black cotton, and the climate is hot and humid with an average annual air temperature of $25^{\circ} \mathrm{C}$. Rainfall is bimodal, peaking in April-June and September-November. The annual dry and hot period is from January to March [21]. The community in Lambwe Valley practice subsistence farming, fishing, and animal husbandry. In the park, the main grazing and browsing wild ruminant populations consist of roan antelope (Hippotragus equinus langheldi), Jackson's hartebeest (Alcelaphus buselaphus Jacksonii), oribi (Ourebia ourebi), and Rothschild giraffes (Giraffa camelopardalis 
rothschildi). The indigenous zebu cattle breed is the dominant domestic species followed by small ruminants. Livestock graze in the open fields extending to the park's fence, thus creating an interface for interaction between wildlife and livestock.

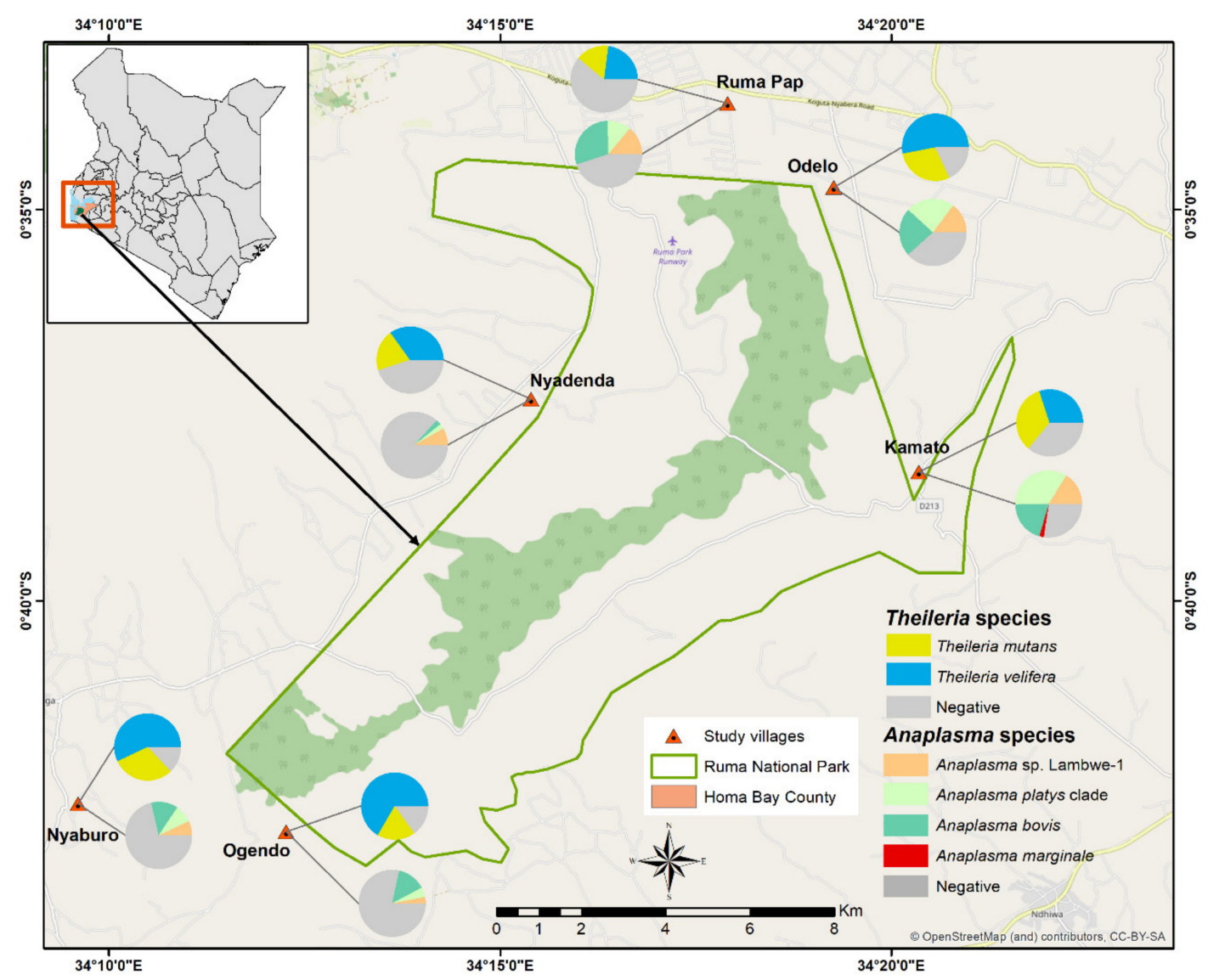

Figure 1. Livestock sampling and tick-borne pathogen (TBP) prevalence map across the the study villages of Lambwe Valley in western Kenya.

\subsection{Study Design and Sample Size Determination}

We used a cross-sectional design with stratified one-stage cluster sampling. All zebu cattle within a $5 \mathrm{~km}$ radius from the park's fence were defined as the study population. Construction of a sampling frame was not possible due to lack of reliable cattle demographic data. Therefore, we defined clusters based on the coordinates of a map grid $\left(3 \mathrm{~km}^{2}\right)$, which later was named after the nearest village (Figure 1). Data were collected between December 2018 and February 2019. Indigenous zebu cattle that were at least one year old and managed in smallholder farms in the wildlife-livestock interface of the Lambwe Valley were considered eligible for the study. This age category is likely to interact with other herds or wildlife at watering points and/or during grazing and is thus amenable to TBP surveillance in the area. Sample sizes were determined based on one-stage cluster sampling using previously described methods [22-24].

The sample size to estimate the prevalence with a specified precision is given by:

$$
\mathrm{N}=\mathrm{gc}=\frac{\mathrm{P}(1-\mathrm{P}) \mathrm{D}}{\mathrm{SE}^{2}}
$$


where $\mathrm{N}$ is the sample size, $\mathrm{P}$ is the prevalence, $\mathrm{D}$ is the design effect, $\mathrm{SE}$ is the standard error of an estimated proportion $\mathrm{P}, \mathrm{g}$ is the average number of animal sampled per cluster, and $\mathrm{c}$ the number of clusters sampled [22]. The design effect was given by the formula,

$$
\mathrm{D}=1+(\mathrm{g}-1) \mathrm{ICC}
$$

We restricted the number of sampled villages (clusters) to $20 \%(c=6)$ of the total 35 clusters, which were selected randomly, but accounting for accessibility. The intra-cluster correlation coefficient (ICC) is a measure of homogeneity of clustered data. We used the ICC value of 0.04 for Anaplasma marginale from previous studies [25]. Considering the possibility to collect a maximum of 100 samples by a team of six people per day per cluster, $\mathrm{D}$ was calculated as 5 (Eqution (2)). Prevalence information for TBPs is limited in the study area. Therefore, the study assumed a prevalence $(\mathrm{P})$ of $50 \%$ for the pathogens. With an expected prevalence of $50 \%$, a cluster size of 6 and the desired precision of $5 \%$, a total sample size of 500 animals was estimated. The study was announced to farmers for sensitisation through local radio, and we accounted for a $25 \%$ non-response rate. To consider the sample size for the non-response rate:

$$
\mathrm{N}=\frac{(\text { Sample size calculated })}{(1-\text { nonresponse rate })}
$$

The above equations gave an estimated sample size of 667 , and the final dataset consisted of a total of 680 cattle.

Epidemiological data on potential risk factors were collected from each sampled household using a questionnaire that captured sex, herd size, herd husbandry practices, grazing system, commonly used acaricides, and the frequency of application.

\subsection{Ethical Approval}

This study strictly adhered to the experimental guidelines and procedures approved by the Institutional Animal Care and Use Committee at International Centre of Insect Physiology and Ecology (icipe) and Kenya's animal welfare laws under the Veterinary Surgeons and Veterinary Para-professionals Act, 2011 (Cap. 366). Blood samples were collected only after receiving informed verbal consent from cattle keepers. Verbal rather than written consent was adopted as the pragmatic approach because all farmers were neither able to read nor write. Blood samples were collected by an experienced veterinarian with the aim of minimising pain and discomfort.

\subsection{Blood Sample Collection and Processing}

Blood samples were collected from the marginal ear vein to assess the anaemia status of each animal by measuring packed cell volume (PCV) using the micro-haematocrit method. Briefly, capillary blood was drawn into ethylenediaminetetraacetic acid (EDTA) microhematocrit tubes and centrifuged at $13,000 \times g$ for $10 \mathrm{~min}$. PCV levels were calculated using the Hawksley haematocrit reader. For molecular detection of pathogens, about $4 \mathrm{~mL}$ of blood was collected from the jugular vein of each cattle using sterile vacutainer needles and EDTA vacutainers. Each tube was identified by a unique animal's ID number. Blood in the EDTA vacutainers were transferred into uniquely-labelled cryovials, stored in liquid nitrogen, and transported to icipe's Martin Lüscher-Emerging Infectious Diseases (ML-EID) Laboratory for molecular analysis.

\subsection{PCR and High-Resolution Melting (HRM) Analysis}

DNA was extracted from blood samples using the Bioline Isolate II genomic DNA kit (Meridian Life Science, Memphis, TN, USA) as described by the manufacturer and screened for the presence of Anaplasma, Theileria, Ehrlichia, Rickettsia, and Babesia spp. by PCR using single-plex genus-specific primers, as shown in Table 1. The $10 \mu \mathrm{L}$ PCR volumes consisted of $2 \mu \mathrm{L}$ of the extracted DNA template, $2 \mu \mathrm{L} 5 \times$ HOT FIREPol ${ }^{\circledR}$ EvaGreen HRM Mix (Solis BioDyne, Tartu, Estonia), $0.5 \mu \mathrm{L}$ each 
of the $10 \mu \mathrm{M}$ forward and reverse primers for the respective genus-specific reactions, and $5 \mu \mathrm{L}$ PCR water. Each assay on different pathogens (Ehrlichia spp., Rickettsia spp., Anaplasma spp., Theileria spp., and Babesia spp.) had a set of known positive controls and a negative control (nuclease-free water) All PCR-HRM reactions were done in the Rotor-Gene Q 5-Plex HRM capable thermocycler (Qiagen, Hannover, Germany). The amplifications involved touchdown PCR conditions including an initial activation of the polymerase enzyme at $95^{\circ} \mathrm{C}$ for $15 \mathrm{~min}$, followed by 35 cycles of denaturation at a temperature of $9^{\circ} \mathrm{C}$ for $20 \mathrm{sec}$. The $25 \mathrm{sec}$ per cycle annealing temperature was reduced by $1^{\circ} \mathrm{C}$ each cycle during the first ten cycles from $65^{\circ} \mathrm{C}$ to $55^{\circ} \mathrm{C}$, and followed by extension at $72{ }^{\circ} \mathrm{C}$ for $25 \mathrm{~s}$ per cycle and a final extension step for $3 \mathrm{~min}$ at $72{ }^{\circ} \mathrm{C}$. Then, the products were maintained for $3 \mathrm{~min}$ at $72{ }^{\circ} \mathrm{C}$ before proceeding with HRM analysis, in which the temperature was gradually increased from $75^{\circ} \mathrm{C}$ to $95{ }^{\circ} \mathrm{C}$ with fluorescence acquisition after $2 \mathrm{~s}$ at $0.1^{\circ} \mathrm{C}$ increments. Changes in fluorescence with change in temperature $(\mathrm{dF} / \mathrm{dT})$ were recorded and plotted. Melt curves were visualised and analysed on Rotor-Gene Q software version 2.3.1 (Qiagen, Hannover, Germany). The graphs were normalised between 100 and $0 \%$ fluorescence. The positive PCR samples were identified by comparing the different melting profiles with the positive controls using the HRM analysis software version 2.1.0 (Qiagen, Hannover, Germany). The PCR products were run in 2\% agarose gels and purified using ExoSap-IT (USB Corporation, Cleveland, OH, USA) as per the manufacturers' instruction and then Sanger sequenced at Macrogen Inc. (Seoul, Korea). Gene sequences produced from this study were deposited in the GenBank database of the National Centre for Biotechnology Information.

Table 1. Primers used in identification of TBPs.

\begin{tabular}{|c|c|c|c|c|c|}
\hline Target Pathogens & $\begin{array}{l}\text { Target } \\
\text { Gene }\end{array}$ & Primer Name & Sequence $\left(5^{\prime}\right.$ to $\left.3^{\prime}\right)$ & $\begin{array}{l}\text { Amplicon } \\
\text { Size (bp) }\end{array}$ & Reference \\
\hline \multirow{2}{*}{ Rickettsia spp. } & \multirow{2}{*}{ 16S rRNA } & Rick-F & GAACGCTATCGGTATGCTTAACACA & \multirow[b]{2}{*}{364} & \multirow[t]{2}{*}{ [26] } \\
\hline & & Rick-R & CATCACTCACTCGGTATTGCTGGA & & \\
\hline \multirow{2}{*}{ Ehrlichia spp. } & \multirow[t]{2}{*}{ 16S rRNA } & EhrlichiaJV F & GCAACCCTCATCCTTAGTTACCA & \multirow{2}{*}{300} & \multirow[t]{2}{*}{ [5] } \\
\hline & & EhrlichiaJV R & TGTTACGACTTCACCCTAGTCAC & & \\
\hline \multirow{2}{*}{ Anaplasma spp. } & \multirow[t]{2}{*}{ 16S rRNA } & AnaplasmaJV F & CGGTGGAGCATGTGGTTTAATTC & \multirow{2}{*}{300} & [5] \\
\hline & & AnaplasmaJV R & CGRCGTTGCAACCTATTGTAGTC & & \\
\hline \multirow[t]{3}{*}{ Anaplasmataceae } & \multirow[t]{3}{*}{$16 \mathrm{~S}$ rRNA } & EHR16SD & GGTACCYACAGAAGAAGTCC & & \multirow[t]{3}{*}{ [27] } \\
\hline & & pH1522 & AAGGAGGTGATCCAGCCGCA & 1060 & \\
\hline & & pH1492 & GGCTACCTTGTTACGACTT & 1030 & \\
\hline \multirow{2}{*}{$\begin{array}{l}\text { Theileria and } \\
\text { Babesia spp. }\end{array}$} & \multirow{2}{*}{ 18S rRNA } & RLB F & GAGGTAGTGACAAGAAATAACAATA & \multirow{2}{*}{450} & \multirow[t]{2}{*}{ [28] } \\
\hline & & RLB R & TCTTCGATCCCCTAACTTTC & & \\
\hline
\end{tabular}

\subsection{Nested PCR for Anaplasma-Positive Samples}

To amplify larger DNA fragments of Anaplasma, we performed nested PCR targeting family Anaplasmataceae 16S rRNA genes [27] in samples with Anaplasma amplicons that had unique HRM profiles. Amplification was done in a TM100 thermal cycler (BioRad, Hercules, CA, USA) in $10 \mu \mathrm{L}$ PCR volumes comprised of $2 \mu \mathrm{L}$ of 5X HOT FIREPol ${ }^{\circledR}$ Blend Master Mix (Solis BioDyne, Tartu, Estonia), $0.5 \mu \mathrm{L}$ each of the $10 \mu \mathrm{M}$ forward and reverse primers, $2 \mu \mathrm{L}$ template, and $5 \mu \mathrm{L}$ PCR-grade water. Primary PCR amplifications using the EHR16SD and pH1522 primers (Table 1) consisted of denaturation at $95^{\circ} \mathrm{C}$ for $15 \mathrm{~min}$ followed by 1 cycle of $95^{\circ} \mathrm{C}$ for $20 \mathrm{~s}, 63^{\circ} \mathrm{C}$ for $30 \mathrm{~s}$, and $72{ }^{\circ} \mathrm{C}$ for $90 \mathrm{~s}$, 2 cycles of $95^{\circ} \mathrm{C}$ for $20 \mathrm{~s}, 62^{\circ} \mathrm{C}$ for $30 \mathrm{~s}$, and $72{ }^{\circ} \mathrm{C}$ for $90 \mathrm{~s}, 2$ cycles of $95^{\circ} \mathrm{C}$ for $20 \mathrm{~s}, 61^{\circ} \mathrm{C}$ for $30 \mathrm{~s}$, and $72{ }^{\circ} \mathrm{C}$ for $90 \mathrm{~s}$, followed with 35 cycles of $95^{\circ} \mathrm{C}$ for $20 \mathrm{sec}, 60^{\circ} \mathrm{C}$ for $30 \mathrm{~s}$, and $72{ }^{\circ} \mathrm{C}$ for $80 \mathrm{~s}$, and the final extension at $72{ }^{\circ} \mathrm{C}$ for $10 \mathrm{~min}$. The nested amplifications used the EHR16SD and pH1492 primers and $1 \mu \mathrm{L}$ of the primary PCR products as templates. The cycling profile consisted of $95^{\circ} \mathrm{C}$ for $15 \mathrm{~min}$; 3 cycles of $95^{\circ} \mathrm{C}$ for $20 \mathrm{~s}, 61^{\circ} \mathrm{C}$ for $30 \mathrm{~s}$, and $72{ }^{\circ} \mathrm{C}$ for $90 \mathrm{~s} ; 37$ cycles of $95^{\circ} \mathrm{C}$ for $20 \mathrm{~s}, 60^{\circ} \mathrm{C}$ for $30 \mathrm{~s}$, and $72{ }^{\circ} \mathrm{C}$ for $80 \mathrm{~s}$, and a final extension at $72{ }^{\circ} \mathrm{C}$ for $10 \mathrm{~min}$. The amplicons were then visualised on an ethidium bromide stained 1\% agarose gel. Samples that had the expected band size of $1030 \mathrm{bp}$ were purified and sequenced, as above. 


\subsection{Phylogenetic Analysis}

All sequences were edited and aligned, using the MAFFT [29] plugin in Geneious Prime version 2019.0.4 software (created by Biomatters, Auckland, New Zealand). They were subsequently queried in the GenBank nr database (http://www.ncbi.nlm.nih.gov/) using the Basic Local Alignment Search Tool (BLAST) [30]. We constructed maximum likelihood phylogenetic relationships of the study's gene sequences to those in GenBank using PhyML version 3.0. [31], employing the Akaike information criterion for automatic model selection. Tree topologies were estimated using nearest neighbor interchange improvements over 1000 bootstrap replicates. Trees were visualised in FIGTREE 1.4.2 [32].

\subsection{Data Management and Analysis}

A database consisting of questionnaire and molecular data was established in MS Excel (Microsoft ${ }^{\circledR}$ Excel, Redmond, WA, USA). Individual- and herd-level information, including animal sex, age, animal weight, anaemia status, herd size, village name, distance of homestead from the park's fence, acaricide use (type and frequency), and infection status, were recorded. The distances of homesteads from the park's fence were measured using a handheld GPS device. Cattle ages were categorised as $\leq 2$ and $>2$ years age groups and small ( $<10$ head of cattle) or medium ( $>10$ head of cattle) herd sizes of smallholder farmers. Anaemia status were categorized into anaemic $(\mathrm{PCV} \leq 24)$ and normal $(\mathrm{PCV}>24)$. After checking and variable coding, data were transferred to SPSS version 25 (IBM Corp, Armonk, NY, USA) for statistical analysis the individual animal and herd levels.

The prevalence of each TBP was calculated by dividing the number of positive samples by the total number of animals sampled during study period. Herd level prevalences were obtained by dividing the number of infected herds by the total number of herds tested. A herd was declared as positive for a TBP if one or more animals within the herd tested positive by PCR-HRM analysis.

Associations between prevalence and putative risk factors of TBPs were analysed using univariable logistic regression models. Risk factors associated with infection with specific TBPs were identified by using a multivariable logistic regression model and the strength of their association was assessed using adjusted odds ratios (OR). Variables with a $p$-value $\leq 0.25$ in univariable analysis were included in a multivariable logistic model. A backward elimination procedure was used for further selection of variables. The variables were tested for interaction effect using cross-product terms and for multiple-collinearity using the collinearity matrix index before building the final model. The model validity and predictive ability were assessed using the Hosmer-Lemeshow test and receiver operating characteristic (ROC) curve. The confidence level was set at $95 \%$ with $\alpha=0.05$.

The datasets supporting the conclusion of this article are included within the article and Supplementary Materials files. Nucleotide sequences reported in this article are available via GenBank.

\section{Results}

\subsection{Pathogen Diversity and Prevalence}

Blood from 680 cattle (370 females and 310 males), mainly zebu (Bos indicus), from 95 herds were screened for presence of TBPs. The average herd size was seven (ranging from 1-21 cattle per herd) and mainly open grazed as their major form of feeding.

Sequencing of PCR amplicons with expected lengths (16S rRNA gene: 1000 bp; $18 \mathrm{~S}$ rRNA gene: 450-500 bp) identified Anaplasma and Theileria infections with the corresponding melting profiles (Figure 2). In the molecular analysis based on PCR-HRM, $311(45.7 \%)$ and $565(82 \%)$ animals were positive for Anaplsma and Theileria species, respectively. A total of 303 sample $(97.4 \%, \mathrm{n}=311)$ and 30 samples $(7 \%, \mathrm{n}=432)$ of the PCR-HRM positive samples were sequenced for Anaplasma and Theileria species, respectively. All of these were confirmed as Anaplasma and Theileria species. Sequence and phylogenetic analysis confirmed the presence of four Anaplasma spp. (Figure 3) and two Theileria spp. (Figure 4). 

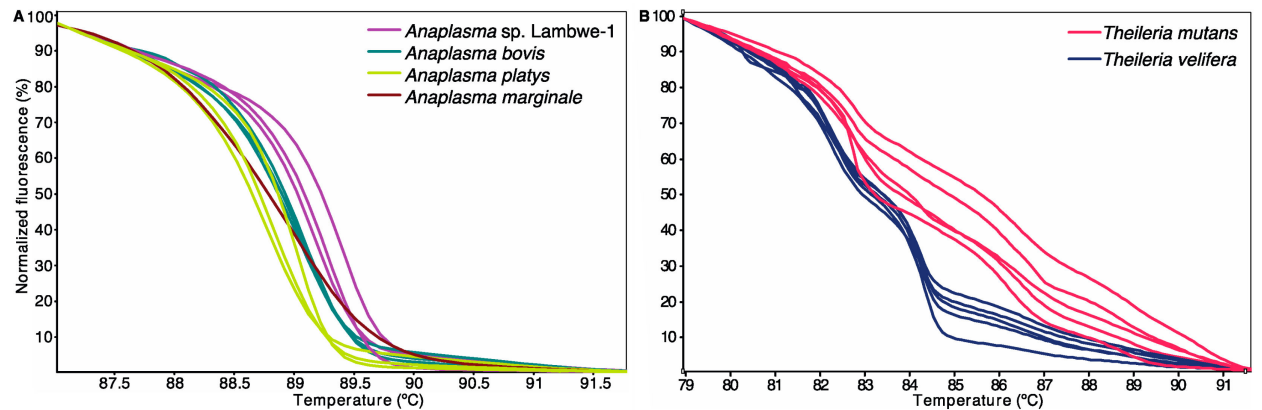

Figure 2. Normalized High-Resolution Melting (HRM) profiles of representative TBP detected (A) Anaplasma spp. and (B) Theileria spp. PCR amplicons.

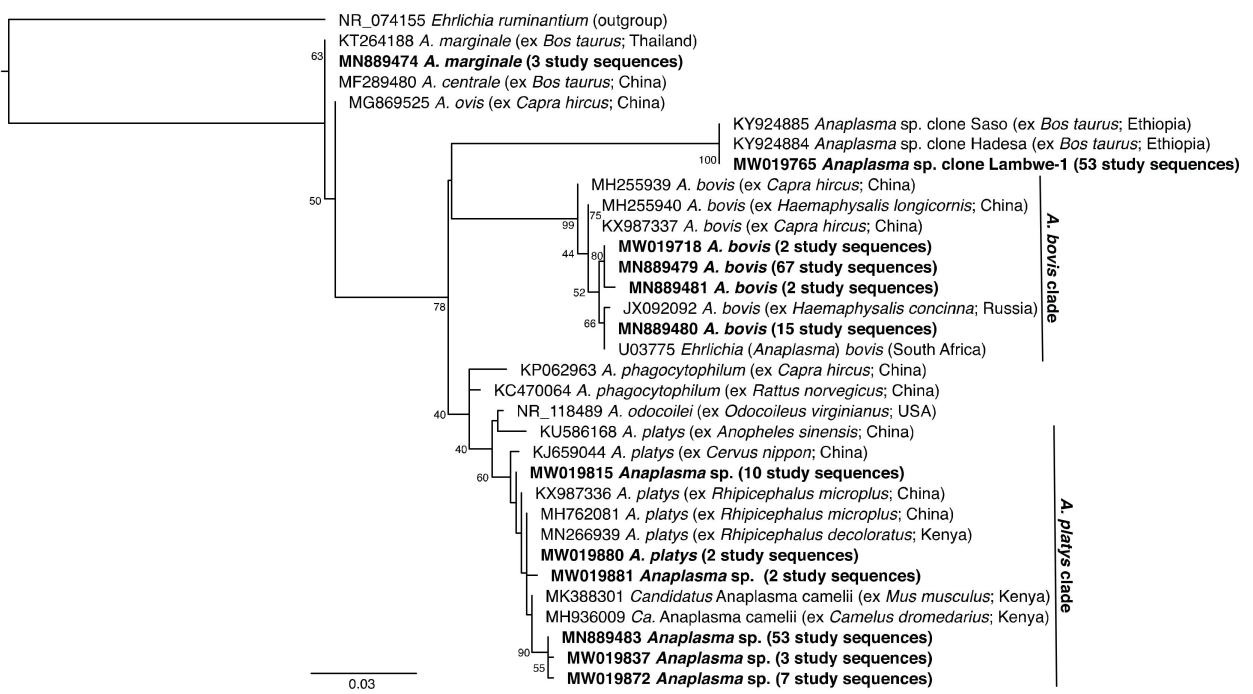

Figure 3. Maximum likelihood phylogeny of 810-bp Anaplasma 16S rRNA sequences from cattle blood samples. GenBank accession numbers, species, host species, and country of origin are indicated for each reference 16S rRNA gene sequence. Sequences obtained in this study are highlighted in bold with the number of samples with specific pathogen sequence identified indicated in brackets. The tree is rooted using the Ehrlichia ruminantium sequence as an outgroup. Bootstrap values at the major nodes represent percent agreement among 1000 replicates. The branch-length scale represents substitutions per site.

We obtained Anaplasma sequences that shared 100\% identity with Anaplasma marginale (deposited GenBank accessions MW019680-MW019681, MN889474; reference GenBank accession MN889474) and > 99\% identity with A. bovis (deposited GenBank accessions MW019682-MW019761, MN889475-MN889481; reference GenBank accession U03775). We also obtained diverse A. platys-like sequences, of which two (deposited GenBank accessions MW019880, MN889489) shared 100\% identity with A. platys from China (reference GenBank accession MH762081), and 75 (deposited GenBank accessions MW019814-MW019879, MW019881-MW019882, MN889483-MN889488, MN889490) shared $>99 \%$ identity with both the A. platys reference sequence and Candidatus Anaplasma camelii from Kenya (reference GenBank accession MH936009) (Figure 3). These A. platys-like sequences are henceforth collectively referred to as A. platys clade sequences. We also obtained an Anaplasma sp. sequence (Lambwe-1) (deposited GenBank accessions MW019762-MW019813, MN889475) that shared 100\% identity to Anaplasma sp. clones "Saso" (GenBank accession KY924885) and "Hadessa" (GenBank accession KY924884) from Ethiopia.

We also identified Theileria mutans nucleotide sequences (deposited GenBank accessions MN853552-MN853559) sharing 100\% identity with a T. mutans from Uganda (GenBank accession KU206320), and Theileria velifera sequences (deposited GenBank accessions MN853560-MN853570) 
sharing 100\% identity with T. velifera from Tanzania (GenBank accession AF097993) and Uganda (GenBank accession KU206307). All cattle samples tested negative for Ehrlichia 16S rRNA, Rickettsia $16 \mathrm{~S}$ rRNA, and Babesia 18S rRNA sequences. Additionally, non-specific amplifications using the long Anaplasma primers led to sequencing of a Wolbachia sp. (deposited GenBank accession MW019883) in four cattle samples.

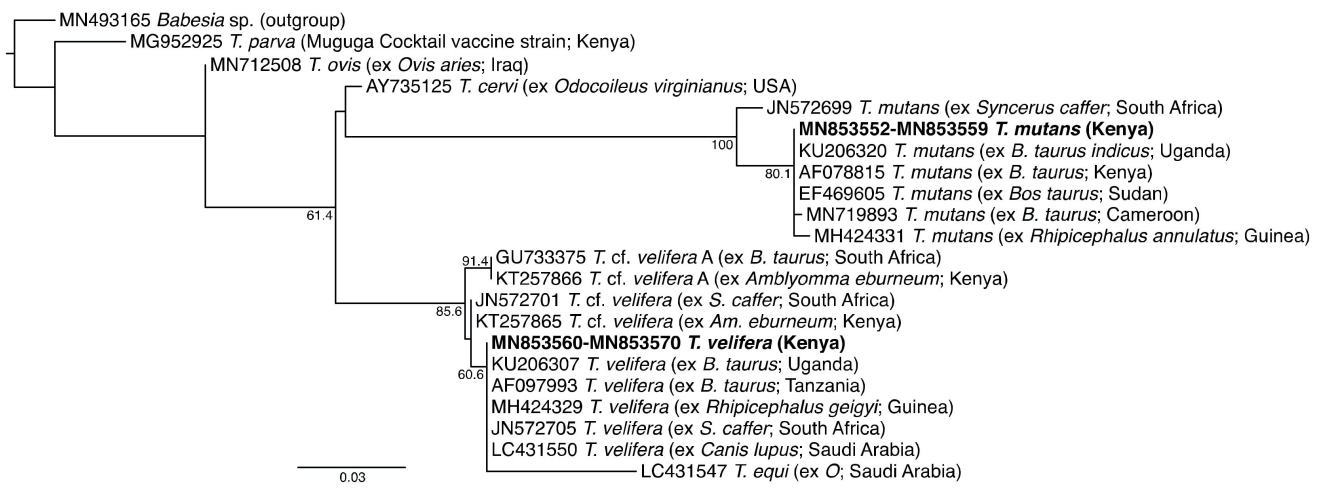

Figure 4. Maximum likelihood phylogeny of 454-bp Theileria 18S rRNA sequences from cattle blood samples. GenBank accession numbers, species, host species, and country of origin are indicated for each reference $18 \mathrm{~S}$ rRNA gene sequence. Sequences obtained in this study are highlighted in bold and countries of origin are indicated in brackets. The tree is rooted using the Babesia sp. sequence as an outgroup. Bootstrap values at the major nodes represent percent agreement among 1000 replicates. The branch-length scale represents substitutions per site.

The apparent prevalence of TBPs at animal- and herd-levels were 78.5\% (95\% CI: 75.3, 81.5) and 95.8\% (95\% CI: 91.8, 99.8), respectively (Table 2). The prevalence of Anaplasma species was $45.7 \%$ (95\% CI: 42, 49.5) at animal level and 78.9\% (95\% CI: 70.8, 87.2) at herd level. For Theileria, we recorded a $63.5 \%$ (95\% CI: 59.9, 67.2) animal-level prevalence and 88.4\% (95\% CI: 82.0, 94.9) herd-level prevalence. The prevalences of A. bovis, A. marginale, Anaplasma sp. Lambwe-1, and A. platys clade sequenses, as well as the two Theileria species, are shown in Table 2.

Table 2. Individual animal- and herd-level apparent prevalences of TBPs in cattle at the wildlife-livestock interface of Lambwe Valley, western Kenya, 2018/2019.

\begin{tabular}{ccccccc}
\hline \multirow{2}{*}{ Pathogen } & \multicolumn{3}{c}{ Individual Prevalence } & \multicolumn{3}{c}{ Herd Prevalence } \\
\cline { 2 - 7 } & $\mathbf{n}^{\mathbf{a}}$ & Prevalence (\%) & $\mathbf{9 5 \%} \mathbf{C I}$ & $\mathbf{n}^{\mathbf{b}}$ & Prevalence (\%) & $\mathbf{9 5 \%} \mathbf{C I}$ \\
\hline Anaplasma spp. & 311 & 45.7 & $42.0,49.5$ & 75 & 78.9 & $70.8,87.2$ \\
A. bovis & 118 & 17.4 & $14.5,20.2$ & 55 & 57.9 & $48.0,67.8$ \\
A. platys clade & 115 & 16.9 & $14.1,19.7$ & 49 & 51.6 & $41.5,61.6$ \\
A. marginale & 4 & 0.6 & $0.0,1.2$ & 4 & 4.2 & $0.2,8.3$ \\
Anaplasma sp. Lambwe-1 & 79 & 11.6 & $9.2,14.0$ & 39 & 41.1 & $31.2,50.9$ \\
Theileria spp. & 432 & 63.5 & $59.9,67.2$ & 84 & 88.4 & $82.0,94.9$ \\
T. velifera & 272 & 40.0 & $36.3,43.7$ & 72 & 75.8 & $67.2,84.4$ \\
T. mutans & 175 & 25.7 & $22.5,29.0$ & 62 & 65.3 & $55.7,74.8$ \\
Overall TBPs & 680 & 78.5 & $75.3,81.5$ & 91 & 95.8 & $91.8,99.8$ \\
\hline
\end{tabular}

$\mathrm{n}^{\mathrm{a}}$ total individual animals tested positive out of $680, \mathrm{n}^{\mathrm{b}}$ total number of herds tested positive out of 95 herds.

\subsection{Risk Factors Associated with Anaplasma and Theileria Infections}

Results of the univariable logistic regression are summarised in Tables S2 and S3 and Figure 1. Each of the identified TBPs $(n=6)$ was used as an outcome in independent logistic regression analyses. Our study considered village, herd size, sex, age and distance from park as the risk factors. Small and medium herds were the herd size found in Lambwe Valley, while the distance considered was 
$\leq 1 \mathrm{~km}$ from the park and $>1 \mathrm{~km}$ from the park. During the univariate analysis, the first level of each independent variable was used as a reference category. The results indicate that herd size, animal sex, and distance from the park were not significantly associated with the presence of any of the Anaplasma and Theileria species. However, there was a significant association between the identified Anaplasma and Theileria species and geospatially clustered villages in which the odds of infection in Kamato, Odelo, and Ruma Pap were significantly higher (Tables S2 and S3).

With the exception of $A$. marginale, all the Anaplasma species were detected in all the study villages. The presence of $A$. marginale was confirmed in only two villages, Kamato and Ruma Pap. The odds of A. platys clade, $A$. bovis, and Anaplasma sp. Lambwe-1 infection were highest in Kamato, Odelo, and Ruma pap (Table S2). The age of the animal was found to be significantly associated with Theileria infection; adults had higher odds of infection ( $\mathrm{OR}=1.8, p=0.014)$ compared to calves and weaners. In contrast, the odds of $T$. velifera infection were lower in adult cattle $(\mathrm{OR}=0.5, p=0.005)$ compared to calves and weaners.

\subsection{Prevalence of Co-Infections}

Single infections were most common, with a prevalence of $46.9 \%$ (Table 3 ). A total of 215 cattle $(31.6 \%)$ were co-infected with at least two pathogens. The majority of the co-infections were double infections. The prevalence of double and triple co-infections of TBPs were $29.4 \%$ and $2.2 \%$, respectively. Anaplasma bovis and T. velifera (6.6\%), A. platys clade and T. mutans (5.3\%), and A. platys clade and T. velifera $(5.2 \%)$ were the three most common double co-infections, while A. marginale and T. velifera $(0.3 \%)$ and T. velifera and T. mutans ( $1 \%)$ co-infections were least common. Cattle with double infection had a combination of one of the identified Anaplasma spp. and either T. velifera or T. mutans. Triple infections consisted mainly of Anaplasma sp. Lambwe-1, A. platys clade, and T. mutans (0.4\%); A. bovis, T. mutans, and T. velifera $(0.7 \%)$; and A. platys clade, T. mutans, and T. velifera $(0.6 \%)$.

Table 3. Single and multiple infections detected in cattle in the wildlife-livestock interface in Lambwe Valley, western Kenya.

\begin{tabular}{ccc}
\hline Pathogen Detected & Number Positive (\% Prevalence) & $\mathbf{9 5 \%}$ CI \\
\hline Single infections & $319(46.9)$ & $43.7,50.7$ \\
A. marginale & $2(0.3)$ & $0.0,0.7$ \\
A. bovis & $36(5.3)$ & $3.6,6.9$ \\
A. platys clade & $35(5.2)$ & $3.5,6.8$ \\
Anaplasma sp. Lambwe-1 & $29(4.3)$ & $2.8,5.8$ \\
T. velifera & $145(21.0)$ & $18.2,24.4$ \\
T. mutans & $72(11.0)$ & $8.3,12.9$ \\
\hline Double infections & $200(29.4)$ & $26.0,32.8$ \\
A. bovis + T. mutans & $31(4.6)$ & $3.0,6.1$ \\
A. bovis + T. velifera & $45(6.6)$ & $4.8,8.5$ \\
A. marginale + T. velifera & $2(0.3)$ & $0.0,0.7$ \\
A. platys clade + T. mutans & $36(5.3)$ & $3.5,6.8$ \\
A. platys clade + T. velifera & $35(5.2)$ & $3.5,6.8$ \\
Anaplasma sp. Lambwe-1 + T. velifera & $29(4.3)$ & $2.8,5.8$ \\
Anaplasma sp. Lambwe-1 + T. mutans & $17(2.5)$ & $1.3,3.7$ \\
T. velifera + T. mutans & $6(1.0)$ & $0.2,1.6$ \\
\hline Triple infections & $15(2.2)$ & $1.1,3.3$ \\
A. bovis + A. platys clade + T. mutans & $1(0.2)$ & $0.0,0.4$ \\
Anaplasma sp. Lambwe-1 + A. platys clade + T. mutans & $3(0.4)$ & $0.0,0.9$ \\
Anaplasma sp. Lambwe-1 + A. platys clade + T. velifera & $1(0.2)$ & $0.0,0.4$ \\
A. bovis + T. velifera + T. mutans & $5(0.7)$ & $0.0,1.4$ \\
\hline Total clade + T. mutans + T. velifera & $4(0.6)$ & $0.0,1.2$ \\
\hline
\end{tabular}




\section{Discussion}

This study provides insight into the diversity and complex co-occurrence of TBPs in cattle from smallholder farms at the wildlife-livestock interface of Ruma National Park, a protected wildlife area in Kenya. The findings show that cattle are infected with at least four Anaplasma species and two Theileria species. They further establish that known pathogens such as A. marginale, A. bovis, T. mutans, and T. velifera are prevalent in cattle from the study area. Notably, the study provides molecular evidence of $A$. platys and an Anaplasma spp. with unknown pathogenicity to livestock or humans.

The overall high prevalence of TBPs found in this study mirrors those recorded in Kenya and other countries in the region within the last five years. We found a TBP prevalence of $78.5 \%$ around Ruma. Regionally, reported TBP prevalence in cattle have ranged from $64.5 \%$ in Tanzania [33], 75.6\% in central Uganda [34] and 89.6\% in western Kenya [12], to 96.9\% in Ethiopia [35]. The high prevalence of TBPs in cattle around Ruma and the region shows that TBPs could be a significant constraint to animal productivity in the majority of herds.

Three pathogens reported here, A. bovis, A. platys, and A. marginale, are known causative agents of bovine anaplasmosis. The clinical manifestation of infections with these pathogens include anaemia, fever, abortion, weight loss, lymphadenopathy, and death [7]. These symptoms are consistent with those described by local farmers from the study area and suggest that these TBPs could have contributed to the outbreak experienced in the area before the study.

This study reports infections of cattle with $A$. bovis and A. platys. Of these, A. bovis, was most prevalent $(17.4 \%)$ and present in all sampled villages. However, this is lower than previously reported in calves (39.9\%) in western Kenya [12]. Several tick species, including Rhipicephalus appendiculatus, Amblyomma variegatum, Hyalomma sp., Rhipicephalus sanguineus, and Haemaphysalis spp. transmit A. bovis [36]. Indeed, a study in western Baringo, Kenya, found that about 3\% of the Amblyomma ticks collected from livestock had A. bovis [37]. Anaplasma platys commonly infects dog platelets and also causes illness in humans [38]. Matei et al. [39] confirmed that dogs roaming rural communities in islands off the Kenyan coast were infected with $A$. platys. This study, however, found A. platys-like DNA in $16.9 \%$ of cattle in the study area, a prevalence notably higher than reported in cattle in China (4.35\%) [40], Tunisia (3.5\%) [41], Brazil (4.75\%) [42], and Kenya [43]. However, as there was considerable sequence variation among $A$. platys clade sequences, our findings may represent an unknown diversity of $A$. platys-like pathogens circulating in the region as found in Tunisia [41].

This study recorded a very low prevalence of $A$. marginale $(0.6 \%)$. In a cross-sectional study conducted in two semi-intensively managed dairy farms in Machakos and Ngong districts, Adjou Moumouni et al. [44] reported A. marginale prevalence of up to 32.5\%. Similarly, higher A. marginale prevalences were reported in Uganda (57\%) [45] and Ethiopia (14.5\%) [35]. Cattle breeds are differently susceptible to bovine anaplasmosis, with crossbreeds known to have relatively higher prevalences than indigenous cattle breeds [35,45]. The animals in this study were all local breeds.

Although Omondi et al. [37] reported diverse Anaplasma, Ehrlichia, and Rickettsia spp. in Amblyomma and Rhipicephalus ticks sampled from livestock in adjacent areas of Homa Bay County, A. marginale was not identified in the ticks. This complements our data to suggest that $A$. marginale is not prevalent in the region. Similarly, no A. marginale, Ehrlichia spp., nor Babesia spp. were identified in ticks sampled from another wildlife-livestock interface, the Maasai Mara National Reserve [11]. However, A. marginale, as well as T. parva, R. africae, and Babesia bigemina have recently been reported in ticks sampled at livestock markets in Busia County [46], approximately $175 \mathrm{~km}$ north of Homa Bay County, which suggests that there may be significant regional variation in TBP diversity associated with disparate agro-ecological contexts.

In $11.6 \%$ of the cattle sampled, we also identified a distinct Anaplasma sp. Lambwe-1 $16 \mathrm{~S}$ rRNA gene sequence that is identical to a recently identified Anaplasma sp. (clones "Saso" and "Hadesa") in Ethiopia [35]. The pathogenicity of this novel Anaplasma in cattle and other species and its zoonotic potential remains unknown. Since all of the sampled cattle in this study were apparently healthy, the 
present study did not evaluate the effect of the identified Anaplasma sp. However, the presence of Anaplasma sp. Lambwe-1 in the blood was significantly correlated with reduced haematocrite PCV.

We found a higher infection rate with Theileria spp. than with Anaplasma spp., with T. mutans at $25.7 \%$ and T. velifera at $40 \%$. These pathogens, transmitted by several Amblyomma tick species, are less pathogenic and commonly found in cattle [5,47]. Our findings are consistent with most from the horn of Africa and southern Africa, which found higher prevalences of T. mutans and T. velifera in cattle compared to other TBPs [12,48]. Infections with $T$. velifera in cattle are mostly asymptomatic with animals infected at younger ages having lifelong infections [35,48,49]. Herd prevalences of Anaplasma spp. $(78.9 \%)$ and Theileria spp. $(88.4 \%)$ were higher than their respective individual prevalences of $45.7 \%$ and $63.5 \%$. Higher herd prevalence may indicate that the pathogens are more broadly distributed than can be assessed by individual prevalence alone. High herd infection prevalence poses a concern on the herd health of cattle in Lambwe Valley.

Our study provides the first detailed analysis of co-infections in bovine species in Lambwe Valley. The high prevalence of co-infection was mainly due to double infection, the highest rates of which were for A. bovis and T. velifera (33\%), and for Anaplasma sp. Lambwe-1 and T. mutans (31\%) co-infections. The overall prevalence of TBP co-infection was, however, lower than previous studies in western Kenya [12]. Njiiri et al. [12] showed that $87.1 \%$ of cattle had mixed infections and that $T$. velifera, Theileria sp. clone "sable", and T. mutans were more prominent. In Ethiopia, Hailemariam et al. [35] reported a higher rate $(57.9 \%)$ of relatively more diverse co-infection ranging from double to sextuple pathogen coinfections. Co-infections can augment transmission of pathogens and/or promote the severity of the diseases [50]. In co-infected animals, the clinical symptoms may not be similar to those in hosts with single infections. Woolhouse et al. [51] demonstrated that mild Theileria species reduced the severity of East Coast fever infection in Kenya. This study does not investigate the implication of co-infections to the burden of disease in Lambwe Valley. It however confirms that co-infections do occur in the wildlife-livestock interface and could lead to misdiagnosis and mismanagement of livestock diseases. In addition to co-infections, we found Wolbachia, an obligate endobacterial symbiont of bovine Onchocerca species that serves as a source of energy for filarial nematodes [52]. Its detection in bovine blood suggests an occult infection of filarial nematodes.

Our risk factor analysis showed that livestock from different villages were at different risks of infection with TBPs. No significant risks were associated with the sex of the animals, the sizes of herds they came from, or the distances of respective homesteads from Ruma National Park. Three village clusters north-east of the park had Anaplasma species prevalences $>75 \%$, while three in the west and south-western side had a combined prevalence of $21 \%$ for the same pathogens. The type of grazing, tick control interventions applied in different villages, and the composition and abundance of vectors for the pathogens could explain disparities in prevalence between villages. Unlike this study, a previous study found higher prevalence of $A$. marginale in smaller herd sizes compared to medium and larger herds in Peninsular Malaysia [53]. However, the Lambwe Valley communities practice open grazing and cattle share communal watering points. We had hypothesised that cattle populations nearer to the park share more space and potential contact with wildlife than cattle populations further away from the park. However, our analysis showed that the odds of TBPs infection in cattle that reside in close proximity to the park $(<1 \mathrm{~km})$ are not different from those that reside further away. The extensive grazing and livestock management system in Lambwe Valley means that cattle move and the approach of using fixed distances for herds may be inappropriate. This study did not sample wildlife to determine their exposure status with regard to the targeted pathogens; we were therefore unable to confirm a role of wildlife on the observed molecular prevalences.

In conclusion, this study provides an update on the epidemiological status of TBPs circulating in cattle of Lambwe Valley, Kenya. It highlights the high prevalence of infections in the wildlife-livestock interface and reports the existence of highly pathogenic $A$. marginale and A. bovis, as well as other novel Anaplasma spp., T. mutans, and T. velifera, with considerable co-infection rates. The results presented offer neither proof of inter-species pathogen transmission nor the incrimination of vectors responsible 
for the transmission of different pathogens. However, the findings add emphasis on the need to proactively investigate the prevalence and composition of TBPs in wildlife-livestock interfaces.

Supplementary Materials: The following are available online at http://www.mdpi.com/2076-2607/8/11/1830/s1, Summary result of the univariable logistic analysis of risk factors with dependent genus Anaplasma and genus Theileria infection (Table S1), Anaplasma species (Table S2) and Theileria species (Table S3) in cattle in the wildlife-livestock interface in Lambwe Valley, western Kenya.

Author Contributions: Conceptualisation, M.N.O., J.V., and S.K.; Methodology, D.M., M.N.O., J.V., and S.K.; Validation, J.V. and D.M.; Formal analysis, B.K.O., J.V., and S.K.; Investigation, B.K.O., P.O., M.N.O., D.M., and S.K., Data curation, B.K.O. and S.K.; writing-original draft preparation, B.K.O.; Writing-review and editing, S.K., J.V., J.L.B. and M.N.O.; Visualisation, B.K.O. and S.K.; Supervision, M.N.O. and S.K.; Project administration, D.M.; Funding acquisition, M.N.O and J.V. All authors have read and agreed to the published version of the manuscript.

Funding: This work was supported through the DELTAS Africa Initiative grant \# DEL-15-011 to THRiVE-2. The DELTAS Africa Initiative is an independent funding scheme of the African Academy of Sciences (AAS)'s Alliance for Accelerating Excellence in Science in Africa (AESA) and supported by the New Partnership for Africa's Development Planning and Coordinating Agency (NEPAD Agency) with funding from the Wellcome Trust grant \# 107742/Z/15/Z and the UK government. This study also received financial support from the German Ministry for Economic Cooperation and Development (BMZ) through the Deutsche Gesellschaft für Internationale Zusammenarbeit (GIZ) ICTDL Project Contract Number: 81235250 and Project Number: 18.7860.2-001.00. Additionally, we acknowledge institutional financial support to icipe from the UK's Foreign, Commonwealth \& Development Office (FCDO), the Swedish International Development Cooperation Agency (Sida), the Swiss Agency for Development and Cooperation (SDC), the government of the Republic of Kenya, and the government of the Republic of Ethiopia. The funders had no role in study design, data collection and analysis, decision to design, data collection and analysis, decision to publish, or preparation of the manuscript. The views expressed in this publication are those of the authors and not necessarily those of any of the funding agencies.

Acknowledgments: We wish to thank Kawira Mathenge, Winnie Cherono, Peter Muasa, David Mbuvi, Richard Tumba, Oscar Esibi, Caren Kemunto, and Philip Kolei for the technical support. We also appreciate the administrative assistance of Caroline Muya, mapping help of Emily Kimathi and oversight of Francis McOdimba.

Conflicts of Interest: The authors declare no conflict of interest.

\section{References}

1. Grootenhuis, J.G.; Olubayo, R.O. Disease research in the wildlife-livestock interface in Kenya. Vet. Q. 1993, 15, 55-59. [CrossRef] [PubMed]

2. Caron, A.; Miguel, E.; Gomo, C.; Makaya, P.; Pfukenyi, D.M.; Foggin, C.; Hove, T.; De Garine-Wichatitsky, M. Relationship between burden of infection in ungulate populations and wildlife/livestock interfaces. Epidemiol. Infect. 2013, 141, 1522-1535. [CrossRef] [PubMed]

3. Jones, K.E.; Patel, N.G.; Levy, M.A.; Storeygard, A.; Balk, D.; Gittleman, J.L.; Daszak, P. Global trends in emerging infectious diseases. Nature 2008, 451, 990-993. [CrossRef] [PubMed]

4. Miller, R.S.; Farnsworth, M.L.; Malmberg, J.L. Diseases at the livestock-wildlife interface: Status, challenges, and opportunities in the United States. Prev. Vet. Med. 2013, 110, 119-132. [CrossRef] [PubMed]

5. Mwamuye, M.M.; Kariuki, E.; Omondi, D.; Kabii, J.; Odongo, D.; Masiga, D.; Villinger, J. Novel Rickettsia and emergent tick-borne pathogens: A molecular survey of ticks and tick-borne pathogens in Shimba Hills National Reserve, Kenya. Ticks Tick Borne Dis. 2017, 8, 208-218. [CrossRef] [PubMed]

6. Daszak, P.; Cunningham, A.A.; Hyatt, A.D. Emerging infectious diseases of wildlife- threats to biodiversity and human health. Science 2000, 287, 443-449. [CrossRef] [PubMed]

7. Minjauw, B.; McLeod, A. Tick-Borne Diseases and Poverty. The Impact of Ticks and Tick-Borne Diseases on the Livelihood of Small-Scale and Marginal Livestock Owners in India and Eastern and Southern Africa; Research Report, DFID Animal Health Programme; University of Edinburgh: Edinburgh, UK, 2003.

8. Ngeranwa, J.J.; Shompole, S.P.; Venter, E.H.; Wambugu, A.; Crafford, J.E.; Penzhorn, B.L. Detection of Anaplasma antibodies in wildlife and domestic species in wildlife-livestock interface areas of Kenya by major surface protein 5 competitive inhibition enzyme-linked immunosorbent assay. Onderstepoort J. Vet. Res. 2008, 75, 199-205. [CrossRef]

9. Ndeereh, D.; Muchemi, G.; Thaiyah, A.; Otiende, M.; Angelone-Alasaad, S.; Jowers, M.J. Molecular survey of Coxiella burnetii in wildlife and ticks at wildlife-livestock interfaces in Kenya. Exp. Appl. Acarol. 2017, 72, 277-289. [CrossRef] 
10. Omondi, D.; Masiga, D.K.; Ajamma, Y.U.; Fielding, B.C.; Njoroge, L.; Villinger, J. Unraveling host-vectorarbovirus interactions by two-gene high resolution melting mosquito bloodmeal analysis in a Kenyan wildlife-livestock interface. PLOS ONE 2015, 10, e0134375. [CrossRef]

11. Oundo, J.W.; Villinger, J.; Jeneby, M.; Ong'amo, G.; Otiende, M.Y.; Makhulu, E.E.; Musa, A.A.; Ouso, D.O.; Wambua, L. Pathogens, endosymbionts, and blood-meal sources of host-seeking ticks in the fast-changing Maasai Mara wildlife ecosystem. PLoS ONE 2020, 15, e0228366. [CrossRef]

12. Njiiri, N.E.; Bronsvoort, B.M.d.; Collins, N.E.; Steyn, H.C.; Troskie, M.; Vorster, I.; Thumbi, S.M.; Sibeko, K.P.; Jennings, A.; van Wyk, I.C.; et al. The epidemiology of tick-borne haemoparasites as determined by the reverse line blot hybridization assay in an intensively studied cohort of calves in western Kenya. Vet. Parasitol. 2015, 210, 69-76. [CrossRef]

13. Kock, R.A. What is this infamous "wildlife/livestock disease interface?" A review of current knowledge for the African continent. In Conservation and Development Interventions at the Wildlife/Livestock Interface: Implications for Wildlife, Livestock and Human Health; Osofsky, S.A., Cleaveland, S., Karesh, W.B., Kock, M.D., Nyhus, P.J., Star, L., Yang, A., Eds.; International Union for Conservation of Nature: Cambridge, UK, 2005; pp. 1-13.

14. Morrison, W.I.; Hemmink, J.D.; Toye, P.G. Theileria parva: A parasite of African buffalo, which has adapted to infect and undergo transmission in cattle. Int. J. Parasitol. 2020, 50, 403-412. [CrossRef]

15. Lwande, O.W.; Lutomiah, J.; Obanda, V.; Gakuya, F.; Mutisya, J.; Mulwa, F.; Michuki, G.; Chepkorir, E.; Fischer, A.; Venter, M.; et al. Isolation of tick and mosquito-borne arboviruses from ticks sampled from livestock and wild animal hosts in Ijara District, Kenya. Vector-Borne Zoonotic Dis. 2013, 13, 637-642. [CrossRef]

16. Kenya Wildlife Conservancies Association. State of Wildlife Conservancies in Kenya Report. 2016. Available online: https://kwcakenya.com/download/state-of-wildlife-conservancies-in-kenya-report/ (accessed on 28 October 2020).

17. Muriuki, G.W.; Njoka, T.J.; Reid, R.S.; Nyariki, D.M. Tsetse control and land-use change in Lambwe Valley, south-western Kenya. Agric. Ecosyst. Environ. 2005, 106, 99-107. [CrossRef]

18. Wellde, B.T.; Chumo, D.A.; Reardon, M.J.; Waema, D.; Smith, D.H.; Gibson, W.C.; Wanyama, L.; Siongok, T.A. Epidemiology of Rhodesian sleeping sickness in the Lambwe Valley, Kenya. Ann. Trop. Med. Parasitol. 1989, 83, 43-62. [CrossRef] [PubMed]

19. Ogutu, J.O.; Piepho, H.P.; Said, M.Y.; Ojwang, G.O.; Njino, L.W.; Kifugo, S.C.; Wargute, P.W. Extreme wildlife declines and concurrent increase in livestock numbers in Kenya: What are the causes? PLoS ONE 2016, 11, e0163249. [CrossRef]

20. Morse, S.S. Factors in the Emergence of Infectious Diseases; Price-Smith, A.T., Ed.; Palgrave Macmillan UK: London, UK, 2001; pp. 8-26. [CrossRef]

21. Otieno, D.O.; K'Otuto, G.O.; Jákli, B.; Schröttle, P.; Maina, J.N.; Jung, E.; Onyango, J.C. Spatial heterogeneity in ecosystem structure and productivity in a moist Kenyan savanna. Plant. Ecol. 2011, 212, 769-783. [CrossRef]

22. Bennett, S.; Woods, T.; Liyanage, W.M.; Smith, D.L. A simplified general method for cluster-sample surveys of health in developing countries. World Health Stat. Q. 1991, 44, 98-106.

23. Dohoo, I.R.; Martin, S.W.; Stryhn, H. Veterinary Epidemiologic Research; VER, Inc.: Charlottetown, PE, Canada, 2009; pp. 33-55.

24. Thrusfield, M.V.; Christley, R. Veterinary Epidemiology, 4th ed.; John Wiley \& Sons: Hoboken, NJ, USA, 2018; p. 864.

25. Otte, M.J.; Gumm, I.D. Intra-cluster correlation coefficients of 20 infections calculated from the results of cluster-sample surveys. Prev. Vet. Med. 1997, 31, 147-150. [CrossRef]

26. Nijhof, A.M.; Bodaan, C.; Postigo, M.; Nieuwenhuijs, H.; Opsteegh, M.; Franssen, L.; Jebbink, F.; Jongejan, F. Ticks and associated pathogens collected from domestic animals in the Netherlands. Vector Borne Zoonotic Dis. 2007, 7, 585-595. [CrossRef]

27. Bastos, A.D.S.; Mohammed, O.B.; Bennett, N.C.; Petevinos, C.; Alagaili, A.N. Molecular detection of novel Anaplasmataceae closely related to Anaplasma platys and Ehrlichia canis in the dromedary camel (Camelus dromedarius). Vet. Microbiol. 2015, 179, 310-314. [CrossRef]

28. Georges, K.; Loria, G.R.; Riili, S.; Greco, A.; Caracappa, S.; Jongejan, F.; Sparagano, O. Detection of haemoparasites in cattle by reverse line blot hybridisation with a note on the distribution of ticks in Sicily. Vet. Parasitol. 2001, 99, 273-286. [CrossRef] 
29. Katoh, K.; Standley, D.M. MAFFT multiple sequence alignment software version 7: Improvements in performance and usability. Mol. Biol. Evol. 2013, 30, 772-780. [CrossRef]

30. Altschul, S.F.; Gish, W.; Miller, W.; Myers, E.W.; Lipman, D.J. Basic local alignment search tool. J. Mol. Biol. 1990, 215, 403-410. [CrossRef]

31. Guindon, S.; Dufayard, J.-F.; Lefort, V.; Anisimova, M.; Hordijk, W.; Gascuel, O. New algorithms and methods to estimate maximum-likelihood phylogenies: Assessing the performance of PhyML 3.0. Syst. Biol. 2010, 59, 307-321. [CrossRef]

32. Rambaut, A. FigTree; Version 1.4. 2; University of Edinburgh: Edinburgh, UK, 2014.

33. Ringo, A.E.; Rizk, M.A.; Moumouni, P.F.A.; Liu, M.; Galon, E.M.; Li, Y.; Ji, S.; Tumwebaze, M.; Byamukama, B.; Thekisoe, $\mathrm{O}$. Molecular detection and characterization of tick-borne haemoparasites among cattle on Zanzibar Island, Tanzania. Acta Trop. 2020, 211, 105598. [CrossRef]

34. Tayebwa, D.S.; Vudriko, P.; Tuvshintulga, B.; Guswanto, A.; Nugraha, A.B.; Gantuya, S.; Batiha, G.E.-S.; Musinguzi, S.P.; Komugisha, M.; Bbira, J.S. Molecular epidemiology of Babesia species, Theileria parva, and Anaplasma marginale infecting cattle and the tick control malpractices in Central and Eastern Uganda. Ticks Tick Borne Dis. 2018, 9, 1475-1483. [CrossRef]

35. Hailemariam, Z.; Krucken, J.; Baumann, M.; Ahmed, J.S.; Clausen, P.H.; Nijhof, A.M. Molecular detection of tick-borne pathogens in cattle from Southwestern Ethiopia. PLoS ONE 2017, 12, e0188248. [CrossRef]

36. Battilani, M.; De Arcangeli, S.; Balboni, A.; Dondi, F. Genetic diversity and molecular epidemiology of Anaplasma. Infect. Genet. Evol. 2017, 49, 195-211. [CrossRef]

37. Omondi, D.; Masiga, D.K.; Fielding, B.C.; Kariuki, E.; Ajamma, Y.U.; Mwamuye, M.M.; Ouso, D.O.; Villinger, J Molecular detection of tick-borne pathogen diversities in ticks from livestock and reptiles along the shores and adjacent islands of Lake Victoria and Lake Baringo, Kenya. Front. Vet. Sci. 2017, 4. [CrossRef]

38. Arraga-Alvarado, C.M.; Qurollo, B.A.; Parra, O.C.; Berrueta, M.A.; Hegarty, B.C.; Breitschwerdt, E.B. Case report: Molecular evidence of Anaplasma platys infection in two women from venezuela. Am. J. Trop. Med. Hyg. 2014, 91, 1161-1165. [CrossRef] [PubMed]

39. Matei, I.A.; D'Amico, G.; Yao, P.K.; Ionică, A.M.; Kanyari, P.W.N.; Daskalaki, A.A.; Dumitrache, M.O.; Sándor, A.D.; Gherman, C.M.; Qablan, M. Molecular detection of Anaplasma platys infection in free-roaming dogs and ticks from Kenya and Ivory Coast. Parasit Vectors. 2016, 9, 157. [CrossRef]

40. Zhou, Z.; Li, K.; Sun, Y.; Shi, J.; Li, H.; Chen, Y.; Yang, H.; Li, X.; Wu, B.; Li, X. Molecular epidemiology and risk factors of Anaplasma spp., Babesia spp. and Theileria spp. infection in cattle in Chongqing, China. PLoS ONE 2019, 14, e0215585. [CrossRef]

41. Said, M.B.; Belkahia, H.; El Mabrouk, N.; Saidani, M.; Alberti, A.; Zobba, R.; Cherif, A.; Mahjoub, T.; Bouattour, A.; Messadi, L. Anaplasma platys-like strains in ruminants from Tunisia. Infect. Genet. Evol. 2017, 49, 226-233. [CrossRef]

42. André, M.R.; Calchi, A.C.; Herrera, H.M.; de Souza Zanatto, D.C.; Horta, B.d.C.L.S.; Tasso, J.B.; de Souza Ramos, I.A.; de Mello, V.V.C.; Machado, R.Z. The co-infection with Ehrlichia minasensis, Anaplasma marginale and Anaplasma platys is not associated with anemia in beef cattle in the Brazilian Pantanal. Vet. Parasitol. Reg. Stud. Reports 2020, 21, 100437. [CrossRef]

43. Peter, S.G.; Aboge, G.O.; Kariuki, H.W.; Kanduma, E.G.; Gakuya, D.W.; Maingi, N.; Mulei, C.M.; Mainga, A.O. Molecular prevalence of emerging Anaplasma and Ehrlichia pathogens in apparently healthy dairy cattle in peri-urban Nairobi, Kenya. BMC Vet. Res. 2020, 16, 364. [CrossRef]

44. Adjou Moumouni, P.F.; Aboge, G.O.; Terkawi, M.A.; Masatani, T.; Cao, S.; Kamyingkird, K.; Jirapattharasate, C.; Zhou, M.; Wang, G.; Liu, M.; et al. Molecular detection and characterization of Babesia bovis, Babesia bigemina, Theileria species and Anaplasma marginale isolated from cattle in Kenya. Parasit. Vectors 2015, 8, 496. [CrossRef]

45. Byaruhanga, C.; Collins, N.E.; Knobel, D.; Chaisi, M.E.; Vorster, I.; Steyn, H.C.; Oosthuizen, M.C. Molecular investigation of tick-borne haemoparasite infections among transhumant zebu cattle in Karamoja Region, Uganda. Vet. Parasitol. Reg. Stud. Reports 2016, 3-4, 27-35. [CrossRef] [PubMed]

46. Chiuya, T.; Masiga, D.; Falzon, L.; Bastos, A.; Fevre, E.; Villinger, J. Tick-borne pathogens, including Crimean-Congo haemorrhagic fever virus, at livestock markets and slaughterhouses in western Kenya. Transbound. Emerg. Dis. 2020. [CrossRef]

47. Simuunza, M.; Weir, W.; Courcier, E.; Tait, A.; Shiels, B. Epidemiological analysis of tick-borne diseases in Zambia. Vet. Parasitol. 2011, 175, 331-342. [CrossRef] 
48. Moll, G.; Lohding, A.; Young, A.S.; Leitch, B.L. Epidemiology of theileriosis in calves in an endemic area of Kenya. Vet. Parasitol. 1986, 19, 255-273. [CrossRef]

49. Ringo, A.E.; Aboge, G.O.; Adjou Moumouni, P.F.; Lee, S.H.; Jirapattharasate, C.; Liu, M.; Gao, Y.; Guo, H.; Zheng, W.; Efstratiou, A.; et al. Molecular detection and genetic characterisation of pathogenic Theileria, Anaplasma and Ehrlichia species among apparently healthy sheep in central and western Kenya. Onderstepoort J. Vet. Res. 2019, 86, 1630. [CrossRef] [PubMed]

50. Telfer, S.; Lambin, X.; Birtles, R.; Beldomenico, P.; Burthe, S.; Paterson, S.; Begon, M. Species interactions in a parasite community drive infection risk in a wildlife population. Science 2010, 330, 243-246. [CrossRef]

51. Woolhouse, M.E.J.; Thumbi, S.M.; Jennings, A.; Chase-Topping, M.; Callaby, R.; Kiara, H.; Oosthuizen, M.C.; Mbole-Kariuki, M.N.; Conradie, I.; Handel, I.G.; et al. Co-infections determine patterns of mortality in a population exposed to parasite infection. Sci. Adv. 2015, 1, e1400026. [CrossRef] [PubMed]

52. Darby, A.C.; Armstrong, S.D.; Bah, G.S.; Kaur, G.; Hughes, M.A.; Kay, S.M.; Koldkjær, P.; Rainbow, L.; Radford, A.D.; Blaxter, M.L. Analysis of gene expression from the Wolbachia genome of a filarial nematode supports both metabolic and defensive roles within the symbiosis. Genome Res. 2012, 22, 2467-2477. [CrossRef]

53. Ola-Fadunsin, S.D.; Gimba, F.I.; Abdullah, D.A.; Sharma, R.S.K.; Abdullah, F.J.F.; Sani, R.A. Epidemiology and risk factors associated with Anaplasma marginale infection of cattle in Peninsular Malaysia. Parasitol. Int. 2018, 67, 659-665. [CrossRef]

Publisher's Note: MDPI stays neutral with regard to jurisdictional claims in published maps and institutional affiliations. 